International Business Management 13 (8): 331-344, 2019

ISSN: $1993-5250$

(C) Medwell Journals, 2019

\title{
The Impact of Strategic Leadership on Corporate Social Responsibility: The Mediating Role of Organizational Learning Culture
}

\author{
${ }^{1}$ Mohsin N.A.N. Alharthi, ${ }^{2}$ Gamal S.A. Khalifa, ${ }^{1}$ Ahmed Hamoud Al-Shibami, ${ }^{1}$ Osama Isaacd and \\ ${ }^{1}$ Ibrhim Alrajawi \\ ${ }^{1}$ Faculty of Business and Accountancy, Lincoln University College, Selangor, Malaysia \\ ${ }^{2}$ Faculty of Tourism and Hotels, Fayoum University, Fayoum, Egypt
}

\begin{abstract}
This study employs structural equations modelling via. SMART PLS3 to analyse the 372 valid questionnaires in order to assess the proposed model to identify the factors that influence Corporate Social Responsibility (CSR). General Directorate of Residency and Foreigners Affairs (GDRFA) is the focus of this paper where Organizational Learning Culture (OLC) approach is applied to assess the impact of Strategic Leadership (SL) through Strategic Leadership (SL) on CSR. The study describes the relations among the various constructs. Our resaerch has improved our insight about CSR. Results indicated that the SL significantly predicted OLC which in turn influenced the dependent variable. Further, it was found that SL has an indirect effect on CSR through OLC. The proposed model explained $48.1 \%$ of the variance in CSR
\end{abstract}

Key words: Strategic leadership, organizational learning, corporate social responsibility, UAE, residency, foreigners

\section{INTRODUCTION}

Lately and based on the augmented competition between service providers, along with large development in the service economy has constrained associations to focus greater attention on the nature and quality of services provided to customers (Hussein et al., 2013; Khalifa and Hewedi, 2016; Abou-Shouk and Khalifa, 2017; Khalifa and Ali, 2017; Mohamud et al., 2017). Service quality is mostly related to employee performance (Khalefa, 2015; Khalifa and Fawzy, 2017). With increasing globalization and international competition, the importance of employing, retaining and handling resources that can help to rise competitiveness of establishments has become a critical issue in the achievement of service industries (Qoura and Khalifa, 2016; Agwa et al., 2017; Li et al., 2017; Kalgin et al., 2018; Mohamed et al., 2018).

Corporate Social Responsibility (CSR) thoughts into two of generalizations into business purpose obligation of maximizing the profit within the boundaries of the low and minimal ethical constraints (Carroll, 2016; Porter and Kramer, 2006) and a broader range of obligations toward society (Schwartz, 2017). The concepts of business enterprises have some responsibilities to the society beyond making a profit for stake and shareholders around the countries (Cheng et al., 2014). The business area's community has formed for their organizations with the specialization of social responsibility in order to provide corporations with expertise on the subject of an opportunity for business executive's advance learn from another (Tai and Chuang, 2014). It is always a representation of the society's prevailing opinions and ideas with responsibility. Emerging social trends into society fundamental order need to be promoted. Organizations may support this process and gain profit at the same time in terms of strategic philanthropy. It is contextualized in different sectors, especially, business-related purposes with the thought of profit and responsibility (Grayson and Hodges, 2017; Singh and Kaur, 2016; Korschun et al., 2014; McWilliams, 2015). Business resources should be used for broad social goals according to the corporation to assume certain responsibilities to society beyond. Since, introducing stakeholder's awareness and managing attributions toward CSR activities are key prerequisites strategic benefits and CSR communication in depth (Chandler and Werther, 2014).

In addition, strategic leadership presumes an ability to influence subordinates, superiors, peers and overall organization to a specific goal. Strategic leaders understand the emergent strategy process for the organization's future plan (Schumacker and Lomax, 2004). It has been repeatedly recognized for the critical role of opportunities and decision making of the organization in the perception of innovation (Khalifa and Fawzy, 2017; Maon et al., 2009). Strategic leaders display a sense of power and confidence

Corresponding Author: Gamal S.A. Khalifa Faculty of Hospitality and Tourism, Lincoln University College, Selangor, Malaysia 
and make bold, unconventional and counter-normative decisions (Shamir et al., 1993). They develop an intriguing, ideological vision of the future and present it in an emotionally captivating manner, expressing their confidence that common aspirations can be achieved through collective efforts (Awamleh and Gardner, 1999). In this study strategic leadership influences on organizational learning culture toward corporate social responsibility. Few leaders allow themselves to create thinking about strategy and future plan (Montgomery, 2008). Leaders should provide direction to every part of the organization such as from the corporate to the loading desk. Thus, strategic leadership is the ability of the leaders to create and re-create reasons for the continuous existences within the organization (Carter and Greer, 2013). The leaders must have the capability to remain on eye on how the organization currently adding value and the other eye on change both inside and outside the organization either threaten its position and presents some new opportunities for adding value (Strand, 2014).

Thus, organizational learning culture sustains competitive advantage in continuously changing the dynamic environment (Khalifa and Ali, 2017 Yeo, 2005). A culture of organizational learning enhances many of benefits including inventing knowledge to create innovative and meaningful for the organization (Abd-Elaziz et al., 2015; Kontoghiorghes et al., 2005; Nonaka, 2008). Learning involves of corporate social responsibility in order to the interaction of mental, physical and learning outcomes with behavioral and individual level of structure (Gallagher and Zahavi, 2007). In this study, learning culture highlights the value and beliefs of collective learning in the organization and refers to both implements and context activities. Therefore, it is a tool of a supportive environment and enables to influence knowledge and learning into the individual, group and within the organizational level (Khalifa and Abou-Shouk, 2014; Marsick and Watkins, 2003). In the organizational level, learning shapes to a social structure where learning culture leads to improve financial outcomes and employee attitudes towards work (Badran and Khalifa, 2016; Egan et al., 2004; Ellinger et al., 2002; Qoura and Khalifa, 2016). Extend studies examine the mediating role of an organizational learning culture in changing an organization's attitude regarding corporate social responsibility (Wang et al., 2007). This study attempts to investigate the causal relationship between SL and CSR via. OLC.

Theoretical framework and hypothesis formulation Strategic Leadership (SL): The theory of strategic leadership has evolved into the coalition impact of organizational outcomes, symbolism and social construction of executives (Hambrick and Mason, 1984;
Vera and Crossan, 2004). In contrast, strategic leadership research has mainly focused on executive work, relational activity and strategic decision. It is an ability to influence others to voluntarily make decisions that enhance the prospects for the organization's longterm success while maintaining short-term financial stability (Ireland and Hitt, 1999; House et al., 2013). Accordingly, being strategic that implies a willingness to take the long view and investments require a pre-emptive commitment of resources. It is also a plan with the aim to link ends, ways and means that involves the thinking required to develop complex or volatile knowledge information (Nag et al., 2007; Segal, 1992). The process to a vision for the future communication subordinates, stimulating and motivating followers, enacting with strategic supportive exchanges with followers (Elenkov et al., 2005). Leader-member exchange and traditional personality theory explained the strategic leadership theory on top manager works as a strategic plan for future decision making to achieve the expected goal.

Top level management represents the dominants coalition of the organization (Yukl, 2012). Montgomery (2008) further considered the responsibility of leaders to formulate a challenging view of the future, providing a clear idea where threaten could come from different sides by thinking and doing combined. The uncertain risk, amidst the uncertainty of the future while endless scanning and assessing all of the factors cannot prompt future to threaten completely. In addition, employees of the organization have to have knowledge about the plan to cope with eventualities. Many organizations survive under the illusion that just because they are successful by their strategy. The organization must expect what they inspect in order to base on-premise as like no measure no get $(\mathrm{Nel}$ and Beudeker, 2009). Therefore, strategic leadership plays an important role in connection of organizational learning culture toward corporate social responsibility. Consequently, the following hypothesis is proposed:

- $\mathrm{H}_{1}: \mathrm{SP}$ has a positive effect on CSR

- $\mathrm{H}_{3}$ : $\mathrm{SL}$ has a positive effect on OLC

- $\mathrm{H}_{3}$ : OLC mediates the relationship between SL and CSR

Organizational Learning (OLC): The learning culture of an organization reproduces the values, basic assumption, tradition and established employee behavioral norms (Abou-Shouk and Khalifa, 2017; Skerlavaj et al., 2010). Organizations have prioritized learning that increases social responsibility and profitability (Marsick, 2013). Organizational learning culture desires both process and structural dimension of learning within the organization. 
Learning organization is consist of the capacity of integrating people and structure to move an organization in the continuous learning and change (Joo, 2010). It is driven force for making business profitability by leading employee and acquiring knowledge and develop innovative concepts. In particular, learning culture within the organization impact on workplace where an employee may change their motives and hoard knowledge because sharing intention to get own success (Hung et al., 2010; Joo and Park, 2010). However, the literature describing the learning organization in extended in nature. Many authors have conceptualized learning organization should work in a specific description of how it works improve to CSR with profit and performance. Meanwhile, the culture of the organization refers to the share and manifestation of the organization's behavior, emphasize the common beliefs, values and assumptions of employees. It is accordingly learned by individual and groups as they encounter resolves problems and challenges in the workplace (Sanz-Valle et al., 2011). Thus, organizational learning culture consequences of common assumptions and procedures including automatic patterns of perceiving, behaving, feeling and provide meaning. An organizational learning culture becomes more essential in the consideration of new ideas because of it enables an organization to do in advance to the dynamic environment changes. In fact, it has been characterized in order to value learning and strive for high performnce throgh the learning progression (Dixon, 2017). In this study, the organizational learning culture adopted in order to play role of practice the knowledge within the organization with extended to CSR. Therefore, organizational learning culture relate to the corporate social responsibility in direct relationship. The basic requirement focus a crucial element connecting learning organizational culture are need for positive, supportive psychological climate for learning application and engage in corporate social responsibility (Jo and Joo, 2011; Malik and Danish, 2010). Hence, the following hypothesis is proposed:

\section{- $\mathrm{H}_{4}$ : OLC has a positive effect on CSR}

CSR: Corporate Social Responsibility is strategic concern for corporation in the organization responding to the interest of stakeholder, investors and consumer (Schwartz, 2017). It acts as an umbrella to explain the complex and multi-faceted relationship between society and business to account for the social, economic and environmental impacts of business activity (Jamali et al., 2017). Additionally, one of the most important domain composed in the responsibility is economic that categorized into the manner consistent with expectation philanthropy and reflect different possible motivation (Flammer, 2015). It is captured the activities which intended to have either direct or indirect positive economic impact on the corporation in question. In the recent debate on corporate social responsibility, corporations are often criticized as human rights in their global supply chains as accomplish to repressive regimes but also potential protectors of environment (Schrempf-Stirling and Palazzo, 2016). It is referred to business practice that involve to initiatives and social benefits.

CSR can encompass a wide variety of tactics from company process to charity or implement reliable business operation. Thus, it described the embracing responsibility and encouragement related to environment, consumer, employees, communities and stakeholder (Huda et al., 2018; Wang et al., 2016; Yakovleva, 2017). There are main three categories has been identified related to social responsibility today's business and practicing such as environmental effort, philanthropy and ethical practice. In specific, the organization perceives CSR as mechanism to energies and motivates stakeholders and mange social perception on the role business in societies and communities beyond the core function of producing and selling goods to consumer market. Alexius et al. (2016) considered on sustainability concentrate two particular trends CSR it has become a dedicated organization function with clear reporting line to top managers; coordinating social activities within the organizational structure (Strand, 2014). The strategy or finance plays an important role in strategic decision for CSR activities as well as requiring crucial question on how shareholders resources are invested to allocate greater societal values in terms of organizational perception or societal goodwill (Alexius et al., 2016; Huda et al., 2018; Yakovleva, 2017). In this study, CSR utilise the make organization reputation in terms of providing learning practice and leadership capabilities within the organization. In addition, it plays an important area of research for gaining profit and social responsibility. Hence, it is hypothesized as follows:

The mediating role of OLC: Turnover continues to be a topic of interest among management researchers. A meta-analyses on the determinants of turnover by Griffeth et al. Several studies have also studied both the magnitude and costs of turnover in the service industry (Joo, 2010). High turnover is generally acknowledged as one of the distinguishing features of the hotel and hospitality industry. Manley et al. underline the positive and negative effects of the high turnover rate in the service sector. Some researchers do not see employee turnover to be dysfunctional, however, at the 
organizational level there is strong evidence that higher turnover has replacement and recruitment costs. One reason that a high rate of voluntary turnover is alarming for many managers is the fear that the employees with better skills and abilities will be those who are able to leave whereas those who remain will be those who cannot find other jobs. Moreover in the service industry one of the most crucial intangible costs is the loss of worker confidence for the employees who choose to stay with the organization. As a result, this can affect the level of service provided to the clients. Hence, it is hypothesized as follows:

- $\mathrm{H}_{4}$ : OLC mediates the relationship between SL and C

\section{MATERIALS AND METHODS}

Overview of the proposed research model: For this study, the hypothesized variables and their relationships in the model have been derived from the available literature of the models and theories that have been prescribed in the literature mentioned above. The proposed model can be in Fig. 1. While examining the proposed model, it can be seen that SL and OLC predicts CSR. These relationships are derived from (Gauhara, 2014) for SL, (Gauhara, 2014) for OLC and (Wu et al., 2015) for CSR. The proposed extended model examines the relationship between SL, OLC as antecedent variables that explain CSR as an output variable among employees from GDRFA in the United Arab Emirates. The proposed model has four hypothesis to test.

Development of instrument: A 26-item questionnaire was developed for this study. Because the respondents were Arab-speaking, it was imperative that it be accurately translated from English to Arabic. Back translation was used in this study, a procedure commonly used in cross-cultural surveys to test the accuracy of the translation (Brislin, 1970).

This study applied multi-item Likert scales which have been widely used in the questionnaire-based perception studies (Lee et al., 2009). Unlike actual usage which is measured using a 5-point ranking scale, other variables are subjectively measured using the 5-point Likert scale with 5 being 'Strongly Agree' and 1 being 'Strongly Disagree'. For this study, a pre-testing was conducted with 50 employees from GDRFA, UAE to resolve any ambiguity associated with wording or measurement. Then, the items were pilot-tested to examine their internal consistency. Out of 500 surveys administered GDRFA, 372 employees were returned with complete and valid data. In the final questionnaire, all

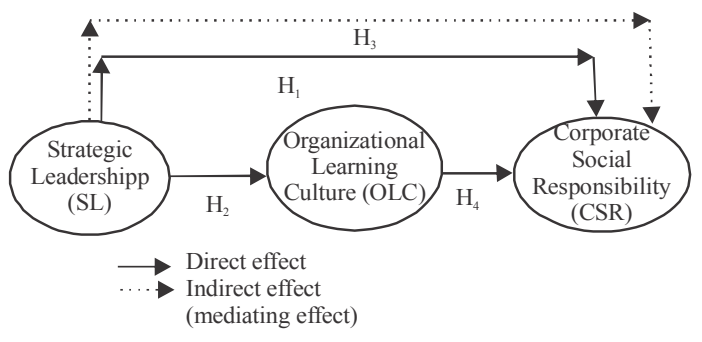

Fig. 1: Proposed resaerch model

items had acceptable reliability as the individual Cronbach's alpha coefficients of the constructs which ranged from 0.874-0.919 were all greater than the recommended value of 0.7 (Nunnally and Bernstein, 1994).

Data collection: Data collection was conducted using a self-administered paper questionnaire which was delivered 'in-person' from October, 2017 until August 2018 to GDRFA, UAE. The researcher investigated 11 GDRFA unit out of 15 unit in UAE. The researcher distributed 500 questioners to the UAE GDRFA's employees, the valid questionnaires received by the researcher are 372 questionnaires by responding rate is $74.4 \%$. The final sample size was considered as adequate (Krejcie and Morgan, 1970; Tabachnick and Fidell, 2012). The $74.4 \%$ response rate is considered very good (Cable and DeRue, 2002) and above average (Baruch and Holtom, 2008) by comparison with other studies found in the relevant literature. A total of 15 questionnaires were deleted of which 10 cases were removed due to missing data for more than $15 \%$ of the questions and 5 cases involving straight lining.

\section{RESULTS AND DISCUSSION}

Descriptive analysis: The responding sample $(n=372)$ consisted of $58.1 \%$ male and $41.9 \%$ female employees which refers that the majority of the GDRFA's employees are male. The majority ages of the participants range from $30-39$ years old. As Table 1 presents that $41.4 \%$ of the respondents were aged $30-39$ years, $28 \%$ of employees are $<30$ years. The employee's educational level is limited by below secondary school, secondary school, Bachelor, Master and $\mathrm{PhD}(7,23.1,58.6,6.5$ and 4.8\%, respectively). Surprisingly, the job tenure of the workers reflects that the period that employees stay at their work are moderate. For instance, more than $66.1 \%$ of those employees stay in their research $<15$ years. Employees nationalities show that $98.4 \%$ of them are local (Table 1). 
Int. Business Manage., 13 (8): 331-344, 2019

Table 1: Summary of demographic profile of respondents

\begin{tabular}{lrc}
\hline Respondents & Frequency & Valid percent \\
\hline Gender & & \\
Male & 216 & 58.10 \\
Female & 156 & 41.90 \\
Age & & \\
$<30$ & 104 & 28.0 \\
$30-39$ & 154 & 41.4 \\
$40-49$ & 87 & 23.4 \\
$50-59$ & 23 & 6.2 \\
60 above & 4 & 1.1 \\
Education & & \\
Below secondary school & 26 & 7.0 \\
secondary school & 86 & 23.1 \\
Bachelor & 218 & 58.6 \\
Msc & 24 & 6.5 \\
PhD & 18 & 4.8 \\
Tenure & & \\
$<5$ years & 77 & 20.7 \\
5-10 & 76 & 20.4 \\
11-15 & 93 & 25.01 \\
16-20 & 71 & 19.1 \\
More than 20 & 55 & 14.8 \\
Nationality & & \\
UAE & 366 & 98.4 \\
Foreigner & 6 & 1.6 \\
\hline
\end{tabular}

Measurement model assessment: This study employed Structural Equation Modeling-Variance Based(SEM-VB) through Partial Least Squares (PLS) method to analyze the research model using the Software of SmartPLS 3.0 (Ringle et al., 2015). After the descriptive analysis, this study follows the two-stage analytical technique recommended by Anderson and Gerbing (1988) and Hair et al. (2017), starts with the measurement model assessment (validity and reliability), followed by the structural model assessment (testing the hypothesized relationships). Schumacker and Lomax (2004) and Hair et al. (2010) indicate that the two steps assessment procedure which includes measurement model and structural model has an advantage over the one step assessment procedure. According to Hair et al. (2017) measurement model specifies how each construct is measured while structural model specifies how the variables are related to each other in the structural model. The main reasons for choosing PLS as a statistical method for this study that for both measurement and structural model PLS offer simultaneous analysis which leads to more accurate estimates (Barclay et al., 1995).

The assessment of measurement model was done through construct reliability as well as validity (including convergent and discriminant validity). For construct reliability. The results indicate that all the individual Cronbach's alpha coefficients ranging from 0.874-0.919 were higher than the suggested value of 0.7 (Kannan and Tan, 2005; Nunnally and Bernstein, 1994). Moreover, the Composite Reliability (CR) values ranging from 0.922 to 0.941 were higher than 0.7 (Werts et al., 1974; Kline, 2010; Gefen et al., 2000). Factor loading: the loadings for all items exceeded the recommended value of 0.5 (Hair et al., 2010) as shown in Table 2. The loading for all items in the model has therefore fulfilled all the requirements. For testing convergent validity this study used the Average Variance Extracted (AVE) and it indicated that all AVE values were higher than the suggested value of 0.50 (Hair et al., 2010) (Table 2).

The results of discriminant validity by using the Fornell-Larcker criterion is shown in Table 3and 4 where the square root of the AVEs on the diagonals as represented by the bolded values are higher than the correlations between constructs (corresponding row and column values) (Fornell and Larcker, 1981; Chin, 1998). Hence, the discriminant validity of all constructs is fulfilled.

There has been some criticism of the Fornell-Larcker criterion, Henseler et al. (2015) mentioned that it does not accurately reveal the lack of discriminant validity in common research situations. They have proposed an alternative technique which is the Heterotrait-Monotrait ratio (HTMT) of correlations based on the multitrait-multimethod matrix. This study assesses discriminant validity through HTMT. While the discriminant validity has a problem when the HTMT value is greater than $\mathrm{HTMT}_{0.90}$ value of 0.90 (Gold et al., 2001) or the $\mathrm{HTMT}_{0.85}$ value of 0.85 (Kline, 2010), all values as Table 5 shows were lower than the recommended value of 0.85 indicating that discriminant validity has been ascertained.

Structural model assessment: Hair et al. (2017) suggested assessing the structural model by looking at the beta $(\beta), \mathrm{R}^{2}$ and the corresponding t-values via. a bootstrapping procedure with a resample of 5,000 . Moreover, they recommend reporting the effect sizes $\left(\mathrm{f}^{2}\right)$ as well as the predictive relevance $\left(\mathrm{Q}^{2}\right)$. As (Sullivan and Feinn, 2012) argue that the $p$-value determine whether the effect exists but it does not reveal the size of the effect.

Hypothesis tests: The structural model assessment as shown in Fig. 2 and Table 6 provides the indication of the hypothesis tests with 3 out of the 3 hypothesis are supported. SL, significantly predict CSR. Hence, $\mathrm{H}_{1}$ is accepted with $(\beta=0.289, \tau=4.186, p<0.001$. SL, significantly predict OLC. Hence, $\mathrm{H}_{2}$ is accepted with $(\beta=0.745 \tau=26.199, p<0.001$. OLC, significantly predict CSR. Hence, $\mathrm{H}_{4}$ is accepted with $(\beta=0.451$, $\tau=7.113 \mathrm{p}<0.001$. SL and OLC are explaining $48.1 \%$ of the variance in CSR. The $\mathrm{R}^{2}$ values achieved an acceptable level of explanatory power as recommended by Cohen (1988) and Chin (1998) indicating a substantial model.

This study also assessed effect sizes $\left(\mathrm{f}^{2}\right)$. Effect size $\mathrm{f}^{2}$ determines whether an exogenous latent construct has a 
Int. Business Manage., 13 (8): 331-344, 2019

Table 2: Mean, standard deviation, loading, Cronbach's alpha, CR and AVE

\begin{tabular}{|c|c|c|c|c|c|c|}
\hline \multirow{2}{*}{\multicolumn{3}{|c|}{$\begin{array}{l}\text { Constructs/items } \\
\text { Organizational Culture Practices (OCP) }\end{array}$}} & MSD & $\alpha(>0.7)$ & $\mathrm{CR}(>0.7)$ & $\operatorname{AVE}(>0.5)$ \\
\hline & & & & & & \\
\hline \multicolumn{2}{|c|}{ OCP1 } & 0.918 & & 0.894 & 0.934 & 0.825 \\
\hline \multicolumn{2}{|l|}{ OCP2 } & 0.906 & & & & \\
\hline \multicolumn{2}{|l|}{ OCP3 } & 0.902 & & & & \\
\hline \multicolumn{7}{|c|}{ Human Capital Practices (HCP) } \\
\hline \multicolumn{2}{|c|}{ HCP1 } & 0.880 & & 0.874 & 0.922 & 0.798 \\
\hline \multicolumn{2}{|l|}{$\mathrm{HCP} 2$} & 0.893 & & & & \\
\hline \multicolumn{2}{|l|}{ HCP3 } & 0.907 & & & & \\
\hline \multicolumn{7}{|c|}{ Strategic Vision Practices (SVP) } \\
\hline \multicolumn{2}{|c|}{ SVP1 } & 0.915 & & 0.907 & 0.941 & 0.843 \\
\hline \multicolumn{2}{|l|}{ SVP2 } & 0.920 & & & & \\
\hline \multicolumn{2}{|l|}{ SVP3 } & 0.919 & & & & \\
\hline \multicolumn{7}{|c|}{ Organizational Control Practices (OCON) } \\
\hline \multicolumn{2}{|l|}{ OCON1 } & 0.919 & & 0.893 & 0.934 & 0.824 \\
\hline \multicolumn{2}{|l|}{ OCON2 } & 0.916 & & & & \\
\hline OCON3 & & 0.888 & & & & \\
\hline Organizat & rning $\mathrm{C}$ & & & & & \\
\hline $\mathrm{OLC1}$ & & 0.733 & & 0.919 & 0.934 & 0.639 \\
\hline OLC2 & & 0.791 & & & & \\
\hline OLC3 & & 0.834 & & & & \\
\hline OLC4 & & 0.846 & & & & \\
\hline OLC5 & & 0.831 & & & & \\
\hline OLC6 & & 0.784 & & & & \\
\hline OLC7 & & 0.798 & & & & \\
\hline OLC8 & & 0.771 & & & & \\
\hline Corporate & esponsi & & & & & \\
\hline CSR1 & & 0.758 & & 0.905 & 0.927 & 0.679 \\
\hline CSR2 & & 0.871 & & & & \\
\hline CSR3 & & 0.862 & & & & \\
\hline CSR4 & & 0.856 & & & & \\
\hline CSR5 & & 0.807 & & & & \\
\hline CSR6 & & 0.783 & & & & \\
\hline $\begin{array}{l}\mathrm{M}=\text { Mean; } \\
\text { is seven po } \\
\text { ( }<0.01 \text { ) }\end{array}$ & $\begin{array}{l}\text { dard D } \\
\text { inging }\end{array}$ & $\begin{array}{l}\text { bach's alpha; } \\
\text { sagree)-7 (stro }\end{array}$ & & adir & idua & $\begin{array}{l}\text { isuren } \\
\text { ally si }\end{array}$ \\
\hline Table 3: Re & liscrimir & he cross loading & & & & \\
\hline Variables & CSR & $\mathrm{HCP}$ & $\mathrm{OCON}$ & $\mathrm{OCP}$ & $\mathrm{OLC}$ & SVP \\
\hline$\overline{\text { CSR1 }}$ & 0.758 & 0.352 & 0.414 & 0.358 & 0.439 & 0.335 \\
\hline CSR2 & 0.871 & 0.508 & 0.423 & 0.410 & 0.624 & 0.489 \\
\hline CSR3 & 0.862 & 0.488 & 0.383 & 0.343 & 0.548 & 0.442 \\
\hline CSR4 & 0.856 & 0.467 & 0.342 & 0.334 & 0.537 & 0.451 \\
\hline CSR5 & 0.807 & 0.502 & 0.361 & 0.512 & 0.577 & 0.480 \\
\hline CSR6 & 0.783 & 0.453 & 0.448 & 0.543 & 0.543 & 0.467 \\
\hline HCP1 & 0.579 & 0.880 & 0.580 & 0.640 & 0.650 & 0.603 \\
\hline HCP2 & 0.445 & 0.893 & 0.450 & 0.505 & 0.601 & 0.528 \\
\hline HCP3 & 0.478 & 0.907 & 0.388 & 0.535 & 0.561 & 0.552 \\
\hline OCON1 & 0.432 & 0.489 & 0.919 & 0.526 & 0.471 & 0.551 \\
\hline OCON2 & 0.455 & 0.448 & 0.916 & 0.520 & 0.508 & 0.559 \\
\hline OCON3 & 0.418 & 0.517 & 0.888 & 0.535 & 0.590 & 0.654 \\
\hline OCP1 & 0.475 & 0.514 & 0.480 & 0.918 & 0.492 & 0.558 \\
\hline OCP2 & 0.430 & 0.605 & 0.587 & 0.906 & 0.532 & 0.577 \\
\hline OCP3 & 0.486 & 0.598 & 0.512 & 0.902 & 0.571 & 0.540 \\
\hline OLC1 & 0.487 & 0.534 & 0.486 & 0.476 & 0.733 & 0.540 \\
\hline OLC2 & 0.500 & 0.590 & 0.432 & 0.416 & 0.791 & 0.533 \\
\hline OLC3 & 0.599 & 0.532 & 0.431 & 0.527 & 0.834 & 0.493 \\
\hline OLCA & 0.605 & 0.498 & 0.490 & 0.474 & 0.846 & 0.555 \\
\hline OLC5 & 0.575 & 0.566 & 0.419 & 0.498 & 0.831 & 0.590 \\
\hline OLC6 & 0.477 & 0.544 & 0.564 & 0.457 & 0.784 & 0.492 \\
\hline OLC7 & 0.561 & 0.518 & 0.412 & 0.450 & 0.798 & 0.524 \\
\hline OLC8 & 0.433 & 0.569 & 0.468 & 0.444 & 0.771 & 0.475 \\
\hline SVP1 & 0.425 & 0.536 & 0.566 & 0.551 & 0.602 & 0.915 \\
\hline SVP2 & 0.536 & 0.609 & 0.568 & 0.581 & 0.592 & 0.920 \\
\hline SVP3 & 0.532 & 0.589 & 0.651 & 0.561 & 0.618 & 0.919 \\
\hline
\end{tabular}

OCP: Organizational Culture Practices; HCP: Human Capital Practices; SVP: Strategic Vision Practices; OCON: Organizational Control Practices; OLC: Organizational Learning culture; CSR: Corporate Social Responsibility 
Int. Business Manage., 13 (8): 331-344, 2019

Table 4: Results of discriminant validity by Fornell-Larcker criterion

\begin{tabular}{|c|c|c|c|c|c|c|}
\hline$\overline{\text { Variables }}$ & CSR & $\mathrm{HCP}$ & OCON & OCP & OLC & SVP \\
\hline$\overline{\mathrm{CSR}}$ & 0.824 & & & & & \\
\hline $\mathrm{HCP}$ & 0.565 & 0.893 & & & & \\
\hline OCON & 0.479 & 0.535 & 0.908 & & & \\
\hline $\mathrm{OCP}$ & 0.510 & 0.631 & 0.581 & 0.908 & & \\
\hline OLC & 0.666 & 0.679 & 0.578 & 0.586 & 0.799 & \\
\hline SVP & 0.543 & 0.630 & 0.649 & 0.615 & 0.658 & 0.918 \\
\hline
\end{tabular}

Diagonals represent the square root of the average variance extract ed while the other entries represent the correlations; OCP: Organizational Culture Practices, HCP: Human Capital Practices, SVP: Strategic Vision Practices, OCON: Organizational Control Practices, OLC: Organizational Learning Culture, CSR: Corporate Social Responsibility

Table 5: Results of discriminant validity by HTMT

\begin{tabular}{|c|c|c|c|c|c|c|}
\hline$\overline{\text { Variables }}$ & CSR & $\mathrm{HCP}$ & OCON & OCP & OLC & SVP \\
\hline \multicolumn{7}{|l|}{$\overline{\mathrm{CSR}}$} \\
\hline $\mathrm{HCP}$ & 0.625 & & & & & \\
\hline OCON & 0.534 & 0.598 & & & & \\
\hline $\mathrm{OCP}$ & 0.563 & 0.708 & 0.648 & & & \\
\hline OLC & 0.722 & 0.757 & 0.638 & 0.645 & & \\
\hline SVP & 0.594 & 0.705 & 0.719 & 0.682 & 0.721 & \\
\hline
\end{tabular}

OCP: Organizational Culture Practices, HCP: Human Capital Practices, SVP: Strategic Vision Practices, OCON: Organizational Control Practices, OLC: Organizational Learning Culture, CSR: Corporate Social Responsibility

Table 6: Structural path analysis result

\begin{tabular}{llllllllll}
\hline Hypothesis & Relationship & Std Beta & SE & t-values & p-values & Decision & $\mathrm{R}^{2}$ & $\mathrm{f}^{2}$ & $\mathrm{Q}^{2}$ \\
\hline $\mathrm{H}_{1}$ & SL - > CSR & 0.289 & 0.285 & 4.186 & 0.000 & Supported & 0.481 & 0.072 & 0.301 \\
$\mathrm{H}_{2}$ & SL - > OLC & 0.745 & 0.747 & 26.199 & 0.000 & Supported & 0.555 & 1.247 & 0.331 \\
$\mathrm{H}_{4}$ & OLC ->CSR & 0.451 & 0.456 & 7.113 & 0.000 & Supported & 0.481 & 0.174 & 0.301 \\
\hline
\end{tabular}

OLC: Organizational Learning Culture, CSR: Corporate Social Responsibility, SL: Strategic Leadership

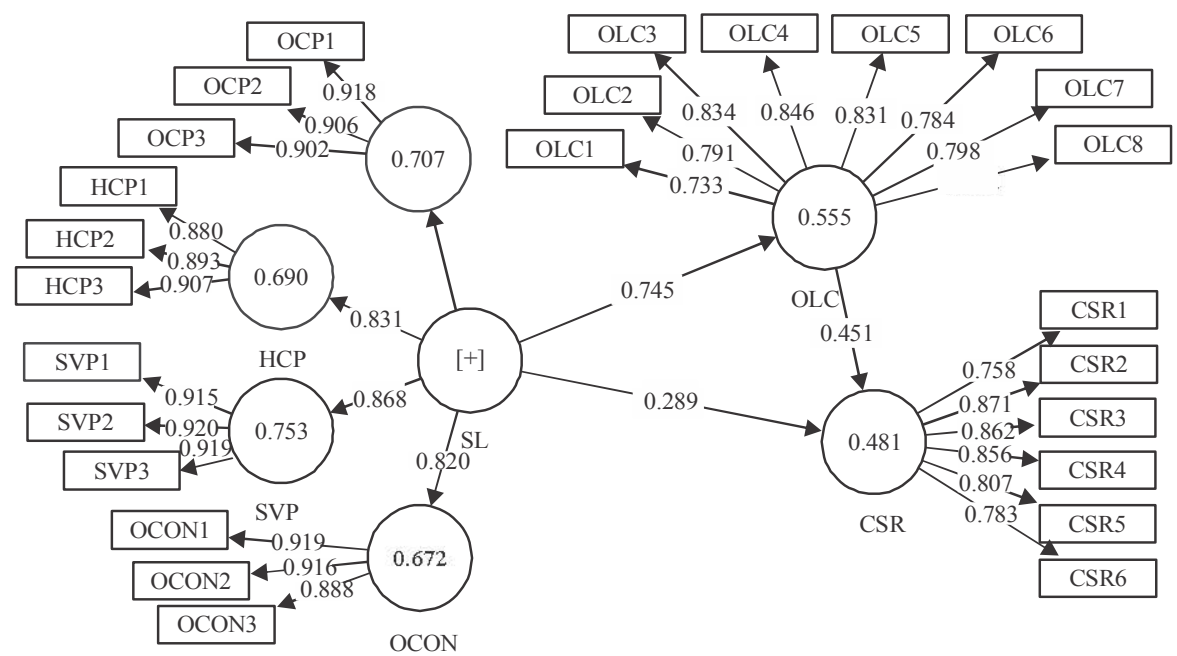

Fig. 2: PLS algorithm results; OCP: Organizational Culture Practices, HCP: Human Capital Practices, SVP: Strategic Vision Practices, OCON: Organizational Control Practices, OLC: Organizational Learning culture, CSR: Corporate Social Responsibility, SL: Strategic Leadership

substantial, moderate or weak impact on an endogenous latent construct (Gefen and Rigdon, 2011). Hair et al. (2017) recommend to test the change in the $\mathrm{R}^{2}$ value. Cohen (1988) suggested a guideline measure the magnitude of the $\mathrm{f}^{2}$ which is 0.35 (large effects), 0.15 (medium effects) and 0.02 (small effects). The result of $\mathrm{f}^{2}$ as Table 4 shows that one relationship with large effect sizes and two relationships with medium effect sizes.
Further by using the blindfolding procedure this study examined the power of research proposed model regarding the predictive relevance. As recommended by Hair et al. (2017) the blindfolding procedure should use only on the endogenous constructs with a reflective measurement. If the value of $Q^{2}$ is $<0$ then the predictive relevance of the proposed model exists for a certain endogenous construct (Fornell and Cha, 1994; Hair et al., 2017). As Table 4 shows that all the values of $Q^{2}$ greater 
Int. Business Manage., 13 (8): 331-344, 2019

Table 7: Bootstrapping the indirect effect of OLC

\begin{tabular}{llccccc}
\hline Hypothesis & Relationship & Std Beta & SE & t-value & p-value & Decision \\
\hline $\mathrm{H}_{3}$ & SL $->$ OLC $->$ CSR & 0.336 & 0.341 & 7.151 & 0.000 & Supported \\
\hline
\end{tabular}

OLC: Organizational Learning Culture, CSR: Corporate Social Responsibility, SL: Strategic Leadership

than zero indicate that there is an adequate predictive relevance for the proposed model. For the $\mathrm{Q}^{2}$ values, Hair et al. (2017) suggested values of 0.35 (large), 0.15 (medium) and 0.02 (small) as a relative measure of predictive relevance and the result of this study shows that the exogenous have medium predictive relevance.

Indirect hypothesis testing (mediation assessment): To test the mediation hypothesis $\mathrm{H}_{4}$, the Preacher and Hayes (2004) and Preacher and Hayes (2008) method of bootstrapping the indirect effect was applied.

- $\mathrm{H}_{4}$ : OLC mediates the relationship between SL and CSR

The bootstrapping analysis showed that the indirect effect was significant with a t-value of 4.646 and $\mathrm{p}<0.001$. Preacher and Hayes (2008) indicated that when the indirect impact of employee performance on organizational productivity through excellence principles with $95 \%$ boot CI: [LL $=0.254$, UL $=0.432$ ] does not straddle a 0 in between, this indicates there is mediation. Thus we can conclude that the mediation effect is statistically significant indicating that $\mathrm{H}_{3}$ was also supported (Table 7).

Waldman et al., (2006) posit that there is a lack of research on managerial variables directly relevant to CSR actions (Thomas and Simerly, 1995). Agle et al., (1999) suggest that instead of focusing on social performance as has largely been the case in prior research, investigators should examine managerial tendencies toward using CSR values in their decision-making because managers are largely responsible for CSR implementation. Based on Waldman et al. (2006), this study suggests that strategic leadership has a significant direct and indirect impact on CSR. SL influences CSR directly and indirectly through mediating variable of OLC. CSR correlates directly with OLC and SL while correlates indirectly with SL. Hence, improved SL will result in better OLC which in turn increase CSR activities. The recognition of OLC as mediators in the relationship between SL and CSR help the GDRFA's management to develop appropriate strategies to improve SL behaviours within the institutions. Based on the proposed model, this study improves the understanding of the role played by SL and OLC in the CSR at GDRFA, UAE and highlights relevant implications and suggestions for management and policy makers. The study found that SL positively affect CSR among employees within the GDRFA in the United Arab
Emirates, this is supported by previous studies (Stogdill, 1974; Thomas and Simerly, 1995; Van Marrewijk, 2003; Finkelstein et al., 2009; Angus-Leppan et al., 2010; Morgeson et al., 2013; Orlitzky, 2013; Chung et al., 2015; Arevalo and Aravind, 2017). It is explained by the fact that the institutional drivers for CSR are thought to come from the national business system and leadership is essential to successful CSR practice (Waldman and Siegel, 2008; Morgeson et al., 2013; Waddock and Bodwell, 2017). In order to enhance SL, GDRFA's management can create projects and activities to form confidence and trust between the followers. Employees who trust the leader's vision and love their jobs are welling to be engaged on CSR activities. Additionally, GDRFA's management should good example the essential organisational standards to help employees to learn and disguise and to have feeling of involvement and accomplishment in the CSR practices. Role modelling at the management level helps to gain respect and trust from the employees. SL is a desirable supervisor behaviour which positively improves employees to CSR activities.

Besides focusing on enhancing SL, GDRFA's management should also pay attention to all antecedents of higher OLC in order to increase CSR. In order to achieve better commitment and engagement, GDRFA's management should help employees to align their objectives to GDRFA's objectives by implementing management by objective strategy. Likewise, it was found that OLC positively affect CSR among employees within the GDRFA in the United Arab Emirates, this is supported by previous studies (Hemingway and Maclagan, 2004; Carter, 2005; Maon et al., 2009; Schrempf-Stirling et al., 2016; Dixon, 2017). Dixon, (2017) highlighted the importance of organizational learning, job engagement as a tool to fuel positive emotions and motivations towards the firm. In addition, Parastoo et al. show the importance of engaging employees in CSR activates and find a suitable job-fit for the employees in order to instil a sense of purpose at work.

\section{CONCLUSION}

The associations among SL and OLC and CSR have been investigated rarely. This study's results provide extra support for these causal relationships, mainly in public sector employees and propose that SL is additional significant factor that indirectly affects these significant job outcomes. Similary, the results also revealed that SL has an indirect effect on CSR via. OLC among employees 
within the GDRFA in the United Arab Emirates which confirms the mediation role that OLC has in this context. This concept has significant value for researchers interested in CSR. Moreover, the variance explained by the proposed model in the current study for CRS among employees within the GDRFA in the United Arab Emirates is $48.1 \%$. Thus, GDRFA's managers who want to foster better OLC and CSR among employees of the GDRFA should take actions to confirm a more SL (Angus-Leppan et al., 2010; Maak et al., 2016). It is explained by the fact that, SL not only has a normative role by encouraging ethical behavior among followers (Brown et al., 2005; Brown and Trevino, 2006, 2014), it also has a positive impact on in-role performance by strengthening subordinate's relationship with their supervisors and increasing employee's attachment to their organizations. Previous studies showed a positive association between CSR and firm performance (Orlitzky, 2013).

\section{LIMITATIONS}

The first limitation concerns the generalizability of the findings, the targeted sampling of this study includes an employee working in GDRFA in the United Arab Emirates only. Another limitation is that data was gathered by cross-sectional and is not longitudinal in nature. The relationships between variables prescribed in the model of this study are highly case-dependent and thus they vary from organization to another, the model was implemented for an example organization which is GDRF. As described in the introduction section of this research. Moreover, the exclusion of other organizational resources for instance, financial resources represents another limitation of the model. Although such resources are necessary for organizations in the successful implementation of their capability-building plans, it was decided that taking into account these organizational resources in the model will result in more unnecessary complications to the model and reduce from the main objectives of this research.

\section{IMPLICATIONS}

Theoretical contribution for research: We have also addressed Waldman and Siegel (2008) concern at a lack of research around leadership behaviour and CSR, finding that an organisation implementing CSR could be using leadership styles as well as allowing for emergent leaders (Angus-Leppan et al., 2010; Orlitzky et al., 2011; Morgeson et al., 2013). This research paper has made use of the available literature of the concept of SL and OLC by applying it to the context of GDRFA in the United
Arab Emirates to examine its role as a source of SL and its effect on the CSR practices. This research can be seen as an attempt to contribute to the understanding of the organizational performance that leads to a firm's enhanced productivity and thus enhanced competitive advantage (Rao, 2016). This concept has significant value for researchers interested in CSR. Moreover, the variance explained by the proposed model in the current study for CSR among employees within GDRFA in the United Arab Emirates is $48.1 \%$. To the best of the researchers knowledge, this study is the first study to examine the mediating role of OLC in the relationship between SL and CSR. The current study has revealed that OLC fully mediate the relationship between SL and CSR. This research offers empirical support to the theoretical relevance of SL and OLC to predict the CSR involvement of organization's employees.

Implication for practice: The present research is of significant for practitioners as it illustrates the importance of SL, CSR and OLC, although, a link of causality between the variables of this study cannot be clearly recognized because of the cross-sectional design, the results indicate that SL and OLC are vital to increase the employee's involvement on CSR activities. The order of this sequence should encourage organizations to put more emphasis on nurturing superviso'r moral person dimension and moral manager one. Moreover, the implications of the key findings provide significant benefits not only for at GDRFA but also to the UAE local government authorities. Incorporating the findings, a number of practical implications were found such as promoting SL behavior as well as OLC which leads to increasing involvement on CSR practices in order to improve the quality of work and the corporate competitive advantages.

It is expected that key findings, especially, the proposed model will help in supporting the UAE government policy initiatives, especially, to increase performance as part of the job at all levels of organizations. The evidence shows a link between CSR involvement and better SL and OLC (Berson et al., 2006; Waldman et al., 2006; Kurland et al., 2010; Sabir et al., 2012; Noruzy et al., 2013; Wiengarten et al., 2017).

\section{REFERENCES}

Abd-Elaziz, M.E., W.M. Aziz, G.S. Khalifa and M. Abdel-Aleem, 2015. Determinants of Electronic Word of Mouth (EWOM) influence on hotel customers purchasing decision. Intl. J. Heritage Tourism Hospitality, 9: 194-223. 
Abou-Shouk, M.A. and G.S. Khalifa, 2017. The influence of website quality dimensions on E-purchasing behaviour and E-loyalty: A comparative study of Egyptian travel agents and hotels. J. Travel Tourism Marketing, 34: 608-623.

Agle, B.R., R.K. Mitchell and J.A. Sonnenfeld, 1999. Who matters to CEOS: An investigation of stakeholder attributes and salience, corporate performance and CEO values. Acad. Manage. J., 42: 507-525.

Agwa, Y., W. Aziz and G. Khalifa, 2017. Evaluating food and beverage courses in higher private tourism and hotels institutes in Alexandria: Professionals perception. Intl. J. Heritage Tourism Hospitality, 11: 98-110.

Alexius, S., S. Furusten and A. Werr, 2016. The 5 as Flies Around Goodies-the Rise of Experts and Services in the Emerging Field of CSR and Sustainability. In: The Organization of the Expert Society, Furusten, S. and A. Werr (Eds.). Routlege, London, UK., ISBN:978-1-138-94795-5, pp: 72-87.

Anderson, J.C. and D.W. Gerbing, 1988. Structural equation modeling in practice: $\mathrm{A}$ review and recommended two-step approach. Psychol. Bull., 103: 411-423.

Angus-Leppan, T., L. Metcalf and S. Benn, 2010. Leadership styles and CSR practice: An examination of sensemaking, institutional drivers and CSR leadership. J. Bus. Ethics, 93: 189-213.

Arevalo, J.A. and D. Aravind, 2017. Strategic outcomes in voluntary CSR: Reporting economic and reputational benefits in principles-based initiatives. J. Bus. Ethics, 144: 201-217.

Awamleh, R. and W.L. Gardner, 1999. Perceptions of leader charisma and effectiveness: The effects of vision content, delivery and organizational performance. Leadersh. Q., 10: 345-373.

Badran, N. and G. Khalifa, 2016. Diversity management: Is it an important issue in hotel industry in Egypt? Intl. J. Heritage Tourism Hospitality, 7: 275-286.

Barclay, D.W., C. Higgins and R. Thompson, 1995. The Partial Least Squares (PLS) approach to causal modeling: Personal computer adoption and use as an illustration. Technol. Stud., 2: 285-309.

Baruch, Y. and B.C. Holtom, 2008. Survey response rate levels and trends in organizational research. Hum. Relat., 61: 1139-1160.

Berson, Y., L.A. Nemanich, D.A. Waldman, B.M. Galvin and R.T. Keller, 2006. Leadership and organizational learning: A multiple levels perspective. Leadersh. Q., 17: $577-594$.

Brislin, R.W., 1970. Back-translation for cross-cultural research. J. Cross Cult. Psychol., 1: 185-216.
Brown, M.E. and L.K. Trevino, 2006. Ethical leadership: A review and future directions. Leadership Q., 17: 595-616.

Brown, M.E. and L.K. Trevino, 2014. Do role models matter? An investigation of role modeling as an antecedent of perceived ethical leadership. J. Bus. Ethics, 122: 587-598.

Brown, M.E., L.K. Trevino and D.A. Harrison, 2005. Ethical leadership: A social learning perspective for construct development and testing. Org. Behav. Hum. Decis. Process., 97: 117-134.

Cable, D.M. and D.S. DeRue, 2002. The convergent and discriminant validity of subjective fit perceptions. J. Applied Psychol., 87: 875-884.

Carroll, A.B., 2016. Carrolls pyramid of CSR: Taking another look. Intl. J. Corporate Soc. Responsibility, 1: 1-8.

Carter, C.R., 2005. Purchasing social responsibility and firm performance: The key mediating roles of organizational learning and supplier performance. Intl. J. Phys. Distribution Logistics Manage., 35: 177-194.

Carter, S.M. and C.R. Greer, 2013. Strategic leadership: Values, styles and organizational performance. J. Leadersh. Organizational Stud., 20: 375-393.

Chandler, D. and W.B. Werther, 2014. Strategic Corporate Social Responsibility: Stakeholders, Globalization and Sustainable Value Creation. SAGE Publications, Thousand Oaks, California, USA.,.

Cheng, B., I. Ioannou and G. Serafeim, 2014. Corporate social responsibility and access to finance. Strategic Manage. J., 35: 1-23.

Chin, W., 1998. The Partial Least Squares Approach for Structural Equation Modeling. In: Modern Methods for Business Research, Marcoulides, G.A. (Ed.). Lawrence Erlbaum Associates, New Jersey, pp: 295-336.

Chin, W.W., 1998. Commentary: Issues and opinion on structural equation modeling. MIS Q., 22: 7-16.

Chung, K.H., J.E. Yu, M.G. Choi and J.I. Shin, 2015. The effects of CSR on customer satisfaction and loyalty in China: The moderating role of corporate image. J. Econ. Bus. Manage., 3: 542-547.

Cohen, J., 1988. Statistical Power Analysis for the Behavioral Sciences. 2nd Edn., Lawrence Erlbaum, Hillsdale, New Jersey, USA., ISBN: 0-8058-6283-5, Pages: 128.

Dixon, N.M., 2017. The Organizational Learning Cycle: How We Can Learn Collectively. 2nd Edn., Routledge, Abingdon, UK., ISBN:9781317022152, Pages: 264.

Egan, T.M., B. Yang and K.R. Bartlett, 2004. The effects of organizational learning culture and job satisfaction on motivation to transfer learning and turnover intention. Hum. Resour. Dev. Q., 15: 279-301. 
Elenkov, D.S., W. Judge and P. Wright, 2005. Strategic leadership and executive innovation influence: An international multi-cluster comparative study. Strategic Manage. J., 26: 665-682.

Ellinger, A.D., A.E. Ellinger, B. Yang and S.W. Howton, 2002. The relationship between the learning organization concept and firms' financial performance: An empirical assessment. Hum. Resour. Dev. Q., 13: $5-22$.

Finkelstein, S. and D.C. Hambrick, 1996. Strategic Leadership: Top Executives and their Effects on Organizations. West Publishing Co., St. Paul, MN., ISBN: 9780314046055 , Pages: 457.

Finkelstein, S., D.C. Hambrick and A.A. Cannella Jr, 2009. Strategic Leadership: Theory and Research on Executives, Top Management Teams and Boards. Oxford University Press, Oxford, UK., ISBN:978-0-19-516207-3, Pages: 463.

Flammer, C., 2015. Does corporate social responsibility lead to superior financial performance? A regression discontinuity approach. Manage. Sci., 61: 2549-2568.

Fornell, C. and D.F. Larcker, 1981. Evaluating structural equation models with unobservable variables and measurement error. J. Marketing Res., 18: 39-50.

Fornell, C. and J. Cha, 1994. Partial Least Squares. In: Advanced Methods of Marketing Research, Bagozzi, R.P. (Ed.). Blackwell Publishing Co., Cambridge, pp: 52-78.

Gallagher, S. and D. Zahavi, 2007. The Phenomenological Mind: An Introduction to Philosophy of Mind and Cognitive Science. Routledge Company, Abingdon, UK., ISBN-13: 978-0-415-39121-4, Pages: 242.

Gauhara, A., 2014. Impact of strategic leadership on knowledge sharing: Case study of Algerian hotels group. Master Thesis, University of Biskra, Biskra, Algeria.

Gefen, D. and E.E. Rigdon, 2011. An update and extension to SEM guidelines for administrative and social science research. MIS. Q., 35: 1-7.

Gefen, D., D.W. Straub and M.C. Boudreau, 2000. Structural equation modeling and regression: Guidelines for research practice. Commun. Assoc. Inform. Syst., 4: 1-77.

Gold, A.H., A. Malhotra and A.H. Segars, 2001. Knowledge management: An organizational capabilities perspective. J. Manage. Inform. Syst., 18: 185-214.

Grayson, D. and A. Hodges, 2017. Corporate Social Opportunity! : Seven Steps to Make Corporate Social Responsibility Work for Your Business. 1st Edn., Routledge, Abingdon, UK., ISBN:9781351280877, Pages: 390 .
Hair, J.F., W.C. Black, B.J. Babin and R.E. Anderson, 2010. Multivariate Data Analysis: A Global Perspective. 7th Edn., Pearson Education Inc., Upper Saddle River, NJ., USA., ISBN-13: 9780135153093 , Pages: 800.

Hair, Jr., J.F., G.T.M. Hult, C.M. Ringle and M. Sarstedt, 2017. A Primer on Partial Least Squares Structural Equation Modeling (PLS-SEM). 2nd Edn., Sage Publisher, Thousand Oaks, California.

Hambrick, D.C. and P.A. Mason, 1984. Upper echelons: The organization as a reflection of its top managers. Acad. Manage. Rev., 9: 193-206.

Hemingway, C.A. and P.W. Maclagan, 2004. Managers personal values as drivers of corporate social responsibility. J. Bus. Ethics, 50: 33-44.

Henseler, J., C.M. Ringle and M. Sarstedt, 2015. A new criterion for assesing discriminant validity in variance-based structural equation modeling. J. Acade. Marketing Sci., 43: 115-135.

House, R.J., P.W. Dorfman, M. Javidan, P.J. Hanges and M.F.S. De Luque, 2013. Strategic Leadership Across Cultures: The GLOBE Study of CEO Leadership Behavior and Effectiveness in 24 Countries. SAGE Publications, Thousand Oaks, California, USA., ISBN:978-1-4129-9594-8, Pages: 430.

Huda, M., D. Mulyadi, A.L. Hananto, N.H. Nor Muhamad and K.S.M. Teh et al., 2018. Empowering Corporate Social Responsibility (CSR): Insights from service learning. Soc. Responsibility J., 14: 875-894.

Hung, R.Y.Y., B. Yang, B.Y.H. Lien, G.N. McLean and Y.M. Kuo, 2010. Dynamic capability: Impact of process alignment and organizational learning culture on performance. J. World Bus., 45: 285-294.

Hussein, I.E., M.A. Abou-Shouk and G.S. Khalifa, 2013. Evaluating tourism and hospitality graduates: Perceptions of stakeholders in Egypt. Proceedings of the 3rd Regional Conference on Tourism Research, October 29-31, 2013, Bayview Hotel, Langkawi, Malaysia, pp: 764-774.

Ireland, R.D. and M.A. Hitt, 1999. Achieving and maintaining strategic competitiveness in the 21st Century: The role of strategic leadership. Acad. Manage. Perspect., 13: 43-57.

Jamali, D., P. Lund-Thomsen and S. Jeppesen, 2017. SMEs and CSR in developing countries. Bus. Soc., 56: 11-22.

Jo, S.J. and B.K. Joo, 2011. Knowledge sharing: The influences of learning organization culture, organizational commitment and organizational citizenship behaviors. J. Leadersh. Organizational Stud., 18: 353-364. 
Joo, B.K. and S. Park, 2010. Career satisfaction, organizational commitment and turnover intention: The effects of goal orientation, organizational learning culture and developmental feedback. Leadersh. Organiz. Dev. J., 31: 482-500.

Joo, B.K., 2010. Organizational commitment for knowledge workers: The roles of perceived organizational learning culture, leader-member exchange quality and turnover intention. Hum. Resour. Dev. Q., 21: 69-85.

Kalgin, A., D. Podolskiy, D. Parfenteva and J.W. Campbell, 2018. Performance management and job-goal alignment: A conditional process model of turnover intention in the public sector. Intl. J. Public Sect. Manage., 31: 65-80.

Kannan, V.R. and K.C. Tan, 2005. Just in time, total quality management and supply chain management: Understanding their linkages and impact on business performance. Omega, 33: 153-162.

Khalaf, S.N., M.A. Morsy, G.S. Ahmed and N.A. Ali, 2016. Impact of effective training on employee performance in hotel establishments. Intl. J. Heritage Tourism Hospitality, 10: 92-109.

Khalefa, G.S.A., 2015. Ethnic restaurants meal experience: Egyptian customers perceptions. Intl. J. Heritage Tourism Hospitality, 9: 92-112.

Khalifa, G.S. and E.H.M. Ali, 2017. Managing drivers and boundaries of Information Technology Risk Management (ITRM) to increase Egyptian hotels market share. Intl. J. Recent Trends Bus. Tourism, 1: 12-31.

Khalifa, G.S. and M.A. Abou-Shouk, 2014. Investigating the success factors of hotel websites: The case of Egyptian hotels. Asia Pac. J. Innovation Hospitality Tourism, 3: 131-151.

Khalifa, G.S.A. and M. Hewedi, 2016. Factors affecting hotel website purchasing intentions: Evidence from Egypt. J. Faculty Tourism Hotels, Fayoum Univ., 8: 50-69.

Khalifa, G.S.A. and N.M. Fawzy, 2017. Measuring E-service quality (Expectation Vs. Perception) from travel agencies perspective: An empirical study on egyptian hotel websites. Intl. J. Recent Trends Bus. Tourism, 1: 36-48.

Kline, R.B., 2010. Principles and Practice of Structural Equation Modeling. 3rd Edn., The Guilford Press, New York, USA., ISBN-13: 9781606238769 , Pages: 427.

Kontoghiorghes, C., S.M. Awbre and P.L. Feurig, 2005. Examining the relationship between learning organization characteristics and change adaptation, innovation and organizational performance. Hum. Resour. Dev. Q., 16: 185-212.
Korschun, D., C.B. Bhattacharya and S.D. Swain, 2014. Corporate social responsibility, customer orientation and the job performance of frontline employees. J. Marketing, 78: 20-37.

Krejcie, R.V. and D.W. Morgan, 1970. Determining sample size for research activities. Educ. Psychol. Meas., 30: 607-610.

Kurland, H., H. Peretz and R. Hertz-Lazarowitz, 2010. Leadership style and organizational learning: The mediate effect of school vision. J. Educ. Administration, 48: 7-30.

Lee, B.C., J.O. Yoon and I. Lee, 2009. Learner's acceptance of e-learning in South Korea: Theories and results. Comput. Educ., 53: 1320-1329.

Li, J.J., W.G. Kim and X.R. Zhao, 2017. Multilevel model of management support and casino employee turnover intention. Tourism Manage., 59: 193-204.

Maak, T., N.M. Pless and C. Voegtlin, 2016. Business statesman or shareholder advocate? CEO responsible leadership styles and the micro-foundations of political CSR. J. Manage. Stud., 53: 463-493.

Malik, M.E. and R.Q. Danish, 2010. Impact of motivation to learn and job attitudes on organizational learning culture in a public service organization of Pakistan. South Asian Stud., 25: 217-235.

Maon, F., A. Lindgreen and V. Swaen, 2009. Designing and implementing corporate social responsibility: An integrative framework grounded in theory and practice. J. Bus. Ethics, 87: 71-89.

Marsick, V.J. and K.E. Watkins, 2003. Demonstrating the value of an organizations learning culture: The dimensions of the learning organization questionnaire. Adv. Dev. Hum. Resour., 5: 132-151.

Marsick, V.J., 2013. The Dimensions of a Learning Organization Questionnaire (DLOQ) introduction to the special issue examining DLOQ use over a decade. Adv. Dev. Hum. Resour., 15: 127-132.

McWilliams, A., 2015. Corporate social responsibility. Wiley Encycl. Manage., 1: 1-4.

Mohamed, M.S., G.S.A. Khalifa, M. Nusari, A. Ameen and A.H. Al-Shibami et al., 2018. Effect of organizational excellence and employee performance on organizational productivity within healthcare sector in the UAE. J. Eng. Appl. Sci., 13: 6199-6210.

Mohamud, S.S., G.S.A. Khalifa, A.E. Abuelhassan and S. Kaliyamoorthy, 2017. Investigating the antecedents of coffee shop customers' behavioral intentions in Kuala Lumpur. Intl. J. Recent Trends Bus. Tourism, 1: 1-14.

Montgomery, C.A., 2008. Putting leadership back into strategy. Harv. Bus. Rev., 86: 54-60.

Morgeson, F.P., H. Aguinis, D.A. Waldman and D.S. Siegel, 2013. Extending corporate social responsibility research to the human resource management and organizational behavior domains: A look to the future. Personnel Psychol., 66: 805-824. 
Myers, R.H., 1990. Classical and Modern Regression with Applications. 2nd Edn., Duxbury, Washington.

Nag, R., D.C. Hambrick and M.J. Chen, 2007. What is strategic management, really? Inductive derivation of a consensus definition of the field. Strat. Manage. J., 28: 935-955.

Nel, C. and N. Beudeker, 2009. The Leadership (r) Evolution: Creating a High Performance Organisation. 2nd Edn., Knowres Publishing, Johannesburg, South Africa, ISBN:9781869221652, Pages: 293.

Nonaka, I., 2008. The Knowledge-Creating Company. Harvard Business Review Press, New York, USA.,.

Noruzy, A., V.M. Dalfard, B. Azhdari, S. Nazari-Shirkouhi and A. Rezazadeh, 2013. Relations between transformational leadership, organizational learning, knowledge management, organizational innovation and organizational performance: An empirical investigation of manufacturing firms. Int. J. Adv. Manuf. Technol., 64: 1073-1085.

Nunnally, J.C. and I.H. Bernstein, 1994. Psychometric Theory. 3rd Edn., McGraw-Hill, New York, USA., ISBN-13: 978-0070478497, Pages: 736.

Nusari, M., M. Al Falasi, I. Alrajawy, G.S. Khalifa and O. Isaac, 2018. The impact of project management assets and organizational culture on employee performance. Intl. J. Manage. Hum. Sci., 2: 15-26.

O'Brien, R.M., 2007. A caution regarding rules of thumb for variance inflation factors. Qual. Quantity, 41: 673-690.

Orlitzky, M., 2013. Corporate social responsibility, noise and stock market volatility. Acad. Manage. Perspect., 27: $238-254$.

Orlitzky, M., D.S. Siegel and D.A. Waldman, 2011. Strategic corporate social responsibility and environmental sustainability. Bus. Soc., 50: 6-27.

Porter, M.E. and M.R. Kramer, 2006. The link between competitive advantage and corporate social responsibility. Harvard Bus. Rev., 84: 78-92.

Preacher, K.J. and A.F. Hayes, 2004. SPSS and SAS procedures for estimating indirect effects in simple mediation models. Behav. Res. Meth. Instrum. Comput., 36: 717-731.

Preacher, K.J. and A.F. Hayes, 2008. Asymptotic and resampling strategies for assessing and comparing indirect effects in multiple mediator models. Behav. Res. Methods, 40: 879-891.

Qoura, O. and G.S.A. Khalifa, 2016. The impact of reputation management on hotel image among internal customers: The case of egyptian hotels. Intl. J. Heritage Tourism Hospitality, 7: 261-274.

Rao, M.S., 2016. Collaborate to build effective teams to achieve organizational excellence and effectiveness. Ind. Commer. Training, 48: 24-28.
Ringle, C.M. and M. Sarstedt, 2016. Gain more insight from your PLS-SEM results: The importance-performance map analysis. Ind. Manage. Data Syst., 116: 1865-1886.

Ringle, C.M., S. Wende and J.M. Becker, 2015. SmartPLS 3. SmartPLS GmbH, Boenningstedt..

Sabir, M.S., J.J. Iqbal, K.U. Rehman, K.A. Shah and M. Yameen, 2012. Impact of corporate ethical vaulues on ethical leadership and employee performance. Int. J. Bus. Soc. Sci., 3: 163-171.

Sanz-Valle, R., J.C. Naranjo-Valencia, D. Jimenez-Jimenez and L. Perez-Caballero, 2011. Linking organizational learning with technical innovation and organizational culture. J. Knowledge Manage., 15: 997-1015.

Schoemaker, P.J., S. Krupp and S. Howland, 2013. Strategic leadership: The essential skills. Harv. Bus. Rev., 91: 131-134.

Schrempf-Stirling, J. and G. Palazzo, 2016. Upstream corporate social responsibility: The evolution from contract responsibility to full producer responsibility. Bus. Soc., 55: 491-527.

Schrempf-Stirling, J., G. Palazzo and R.A. Phillips, 2016. Historic corporate social responsibility. Acad. Manage. Rev., 41: 700-719.

Schumacker, R.E. and R.G. Lomax, 2004. A Beginner's Guide to Structural Equation Modeling. 2nd Edn., Lawrence Erlbaum Associates, New Jersey, USA., ISBN:0-8058-4017-6,

Schwartz, M.S., 2017. Corporate Social Responsibility. Taylor \& Francis, Abingdon, UK., ISBN:9781351948401, Pages: 560.

Segal, D.R., 1992. Environmental challenges for strategic managers. Strategic Leadersh. Multiorganizational Level Perspect., 1: 29-44.

Shamir, B., R.J. House and M.B. Arthur, 1993. The motivational effects of charismatic leadership: A self-concept based theory. Organiz. Sci., 4: 577-594.

Singh, S. and P. Kaur, 2016. Corporate social responsibility in India. Intl. J. Res. Anal. Rev., 5: 327-341.

Skerlavaja, M., J.H. Song and Y. Lee, 2010. Organizational learning culture, innovative culture and innovations in South Korean firms. Exp. Syst. Appli., 37: 6390-6403.

Stogdill, R.M., 1974. Handbook of Leadership: A Survey of the Literature. Free Press, New York, USA.

Strand, R., 2014. Strategic leadership of corporate sustainability. J. Bus. Ethics, 123: 687-706.

Sullivan, G.M. and R. Feinn, 2012. Using effect size-or why the $\mathrm{P}$ value is not enough. J. Graduate Med. Educ., 4: 279-282.

Tabachnick, B.G. and L.S. Fidell, 2012. Using Multivariate Statistics. 6th Edn., Pearson Education, Boston, MA., ISBN-13: 9780205849574 , Pages: 983.

Tai, F.M. and S.H. Chuang, 2014. Corporate social responsibility. Ibusiness, 6: 117-130. 
Thomas, A.S. and R.L. Simerly, 1995. Internal Determinants of Corporate Social Performance: The Role of Top Managers. In: Academy of Management Proceedings, Atinc, G. (Ed.). Academy of Management, Briarcliff Manor, New York, pp: 411-415.

Van Marrewijk, M., 2003. Concepts and definitions of CSR and corporate sustainability: Between agency and communion. J. Bus. Ethics, 44: 95-105.

Vera, D. and M. Crossan, 2004. Strategic leadership and organizational learning. Acad. Manage. Rev., 29: 222-240

Waddock, S. and C. Bodwell, 2017. Total Responsibility Management: The Manual. Taylor \& Francis, Abingdon, UK., ISBN:9781351280389, Pages: 192.

Waldman, D.A. and D. Siegel, 2008. Defining the socially responsible leader. Leadership Quart., 19: 117-131

Waldman, D.A., M.S. de Luque, N. Washburn, R.J. House and B. Adetoun et al., 2006. Cultural and leadership predictors of corporate social responsibility values of top management: A GLOBE study of 15 countries. J. Int. Bus. Stud., 37: 823-837.

Wang, H., L. Tong, R. Takeuchi and G. George, 2016. Corporate social responsibility: An overview and new research directions: Thematic issue on corporate social responsibility. Acad. Manage. J., 59: 534-544.
Wang, Y.S., H.Y. Wang and D.Y. Shee, 2007. Measuring e-learning systems success in an organizational context: Scale development and validation. Comput. Human Behav., 23: 1792-1808.

Werts, C.E., R.L. Linn and K.G. Joreskog, 1974. Intraclass reliability estimates: Testing structural assumptions. Educ. Psychol. Meas., 34: 25-33.

Wiengarten, F., C.K. Lo and J.Y. Lam, 2017. How does sustainability leadership affect firm performance? The choices associated with appointing a chief officer of corporate social responsibility. J. Bus. Ethics, 140: 477-493.

Wu, L.Z., H.K. Kwan, F.H.K. Yim, R.K. Chiu and X. He, 2015. CEO ethical leadership and corporate social responsibility: A moderated mediation model. J. Bus. Ethics, 130: 819-831.

Yakovleva, N., 2017. Corporate Social Responsibility in the Mining Industries. 1st Edn., Routledge, Abingdon, UK., ISBN:9781351948388, Pages: 324.

Yeo, R., 2005. Implementing organizational learning initiatives: Insights from Singapore organizations-part I. Dev. Learn. Organizations. Intl. J., 19: 5-7.

Yukl, G., 2012. Effective leadership behavior: What we know and what questions need more attention. Acad. Manage. Perspect., 26: 66-85. 